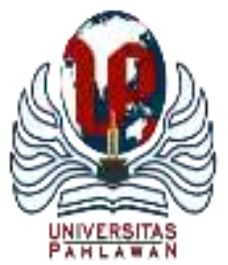

Edukatif : Jurnal Ilmu Pendidikan Volume 3 Nomor 6 Tahun 2021 Halm 4827 - 4835

EDUKATIF: JURNAL ILMU PENDIDIKAN

Research \& Learning in Education

https:/ledukatif.org/index.php/edukatif/index

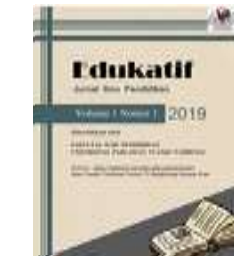

\title{
Peran Guru dalam Meningkatkan Jiwa Nasionalisme Siswa Sekolah Dasar melalui Pembelajaran Pkn di Era Globalisasi
}

\author{
Ghina Fauziah Hazimah ${ }^{1 凶}$, Nabila Ratri Widya Astuti², Dinie Anggraeni Dewi ${ }^{3}$, Yayang Furi \\ Furnamasari $^{4}$ \\ Universitas Pendidikan Indonesia, Indonesia, ${ }^{2,3,4}$

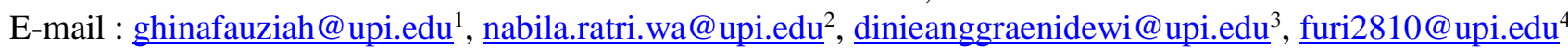

\begin{abstract}
Abstrak
Di era globalisasi yang semakin modern perlu menuntut memiliki jiwa nasionalisme yang semakin tinggi, karena apabila ilmu dan pengetahuan tidak diimbangi dengan rasa nasionalisme menyebabkan hilangnya pendidikan sebagai wadah humanis. Penulis mengangkat judul ini dalam penelitiannya bertujuan agar siswa sekolah dasar di generasi berikutnya memiliki jiwa nasionalisme yang tinggi supaya tidak terpengaruh hal negatif globalisasi. Metode yang digunakan yaitu metode penelitian kualitatif dengan analisis deskriptif melalui pendekatan studi literatur dari berbagai jurnal serta bukubuku yang relevan sebagai referensi. Hasil dari peneletian ini yaitu jiwa nasionalisme dalam diri siswa sudah mulai hilang akibat dampak dari globalisasi. Oleh karena itu guru sangat berperan penting dalam hal ini, upaya yang dilakukan guru yaitu memaksimalkan pembelajaran PKn kepada siswa. Pembelajaran PKn di sekolah sangatlah penting sebagai sarana menanamkan nilai-nilai luhur bangsa kepada siswa agar siswa memiliki jiawa nasionalisme yang tinggi. Selain memberikan pembelajaran PKn, guru juga berperan untuk memberikan contoh perilaku-perilaku yang baik dan menjadi teladan terhadap siswanya serta menjadikan siswa memiliki kemampuan berfikir kritis serta bijak dalam menyikapi berbagai pengaruh di era globalisasi saat ini. Jadi pembelajaran PKn perlu diajarkan dan diterapkan kepada siswa sekolah dasar agar tidak terpengaruh arus globalisasi.
\end{abstract}

Kata Kunci: Peran Guru, Nasionalisme, Pembelajaran PKn di Sekolah Dasar, Globalisasi.

\begin{abstract}
In an increasingly modern era of globalization, it is necessary to demand a higher spirit of nationalism, because if science and knowledge are not balanced with a sense of nationalism, it will cause the loss of education as a humanist forum. The author raised this title in his research aimed at making elementary school students in the next generation have a high spirit of nationalism so that they are not affected by the negative things of globalization. The method used is a qualitative research method with descriptive analysis through a literature study approach from various journals and relevant books as references. The result of this research is that the spirit of nationalism in students has begun to disappear due to the impact of globalization. Therefore, the teacher plays an important role in this case, the efforts made by the teacher are to maximize Civics learning to students. Civics learning in schools is very important as a means of instilling the noble values of the nation in students so that students have a high spirit of nationalism. In addition to providing Civics learning, teachers also play a role in providing examples of good behavior and being an example to their students and making students have the ability to think critically and wisely in responding to various influences in the current era of globalization. So Civics learning needs to be taught and applied to elementary school students so that they are not affected by the flow of globalization.
\end{abstract}

Keywords: Teacher's Role, Nationalism, Civics Learning in Elementary Schools, Globalization.

Copyright (c) 2021 Ghina Fauziah Hazimah, Nabila Ratri Widya Astuti, Dinie Anggraeni Dewi, Yayang Furi Furnamasari

$\triangle$ Corresponding author

Email : ghinafauziah@upi.edu

DOI : https://doi.org/10.31004/edukatif.v3i6.1566

ISSN 2656-8063 (Media Cetak)

ISSN 2656-8071 (Media Online) 
4828 Peran Guru dalam Meningkatkan Jiwa Nasionalisme Siswa Sekolah Dasar melalui Pembelajaran Pkn di Era Globalisasi - Ghina Fauziah Hazimah, Nabila Ratri Widya Astuti, Dinie Anggraeni Dewi, Yayang Furi Furnamasari

DOI: https://doi.org/10.31004/edukatif.v3i6.1566

\section{PENDAHULUAN}

Nasionalisme merupakan suatu kebanggaan Negara yang dapat menimbulkan sikap dan rasa lebih mendahulukan kepentingan negara atau nasional diatas kepentingan pribadi. Puncaknya semangat jiwa nasionalisme yang tinggi pada diri pemuda saat di deklarasikannya sumpah pemuda saat 28 Oktober 1928. Mulai dari era sumpah pemuda tahun 1928 hingga Indonesia merdeka pada tahun 1945, pemuda pemudi bangsa sangat berperan penting dalam peristiwa-peristiwa tersebut. Hal tesebut sebagai salah satu bukti akan peran nasionalisme pemuda dalam sejarah bangsa Indonesia.

Bangsa Indonesia memiliki berbagai masalah internal maupun eksternal yang harus dihadapi dan diselesaikan. Salah satu permasalahan yang dihadapi yaitu memudarnya jiwa nasionalisme pada diri generasi muda. Pudarnya jiwa nasionalisme di diri generasi muda dikarenakan pengaruh arus globalisasi (Lestari, 2019) Hal ini banyak generasi muda yang mudah terpengaruh oleh budaya - budaya asing yang masuk ke bangsa Indonesia dan tidak sedikit generasi bangsa zaman sekarang yang mulai melupakan budaya-budaya Indonesia. Hal ini berakibat generasi bangsa tidak memperhatikan dan mengabaikan nilai-nilai luhur bangsa Indonesia. (Irhandayaningsih, 2012). Dalam sebuah Riset menunjukan bahwa globalisasi menjadi salah satu penyebab kemerosotan moral dan lunturnya nilai-nilai pancasila generasi muda di Indonesia (Wahyudi, 2016)

Dampak arus globalisasi memengaruhi pendidikan seorang anak yaitu dalam hal berpikir, bersikap dan bagaimana bertindak (Sakman, S., \& Bakhtiar, 2019). Dampak negatif dari globalisasi tersebut akan menghilangkan nilai-nilai jati diri bangsa maupun identitas nasional bangsa Indonesia, dan eksistensi Pancasila pun lambat laun akan mengalami kemunduran seiring dengan kemajuan dan perkembangan zaman, pengetahuan, serta teknologi saat ini. (Fitrayadi, 2016) mengatakan jika nilai-nilai luhur Pancasila sudah mulai dilupakan oleh masyarakat Indonesia.

Cara mengatasi hal-hal tersebut agar generasi muda di masa yang akan datang tidak mudah terpengaruhi globalisasi yang membawa dampak negatif yaitu diajarkannya dan menerapkannya pembelajaran PKn. Pendidikan menjadi salah satu faktor penting guna menumbuhkan nasionalisme disamping bahasa dan budaya. Dalam Pendidikan kewarganegaraan itu sendiri sangatlah sarat akan nilai-nilai nasionalisme dan patriotisme (Suryana, 2021). Pendidikan Kewarganegaraan ini sendiri telah menjadi mata pelajaran wajib bag seluruh peserta didik di sekolah formal sebagaiman di atur dalam Undang Undang Nomor 2 Tahun 1989 tentang Sistem Pendidikan Nasional (Rahayu, 2007). Pembelajaran PKn sangatlah berguna untuk membentuk karakter siswa sesuai dengan nila-nilai pancasila, serta menjadi salah satu media belajar bagi siswa untuk lebih mengenal Bangsa Indonesia, dan membentuk generasi yang cinta tanah air. Penanaman nilai-nilai tersebut harus diajarkan sejak dini pada generasi bangsa dan peran gurulah yang sangat penting dalam mewujudkan hal tersebut terkhusus dalam mengajarkan kepada siswa di Sekolah Dasar yang belum paham akan nilai-nilai luhur bangsanya serta mudah terpengaruh berbagai hal-hal yang ada di sekitarnya termasuk dampak buruk dari globalisasi.

Dalam pembelajaran PKn ini banyak sekali yang mempengaruhi hasil belajar siswa. Perlu adanya sinkronisasi dari semua komponen dalam proses pembelajaran yaitu pada guru, materi pembelajaran dan juga siswa. Ketiga komponen tersebut memiliki hubungan timbal balik dan dibutuhkan sarana dan prasarana seperti : metode pembelajaran, model pembelajaran, media serta lingkungan belajar yang baik. Dengan itu akan tercipta suasana belajar yang efektif serta produk pembelajaran akan memiliki makna dalam pembentukan moral, etika serta penumbuhan jiwa nasionalisme pada siswa dan mendorong tercapainya semua tujuan dari pembelajaran PKn. Penelitian ini penting dilakukan karena jiwa nasionalisme sangat penting dan berpengaruh terhadap kehidupan kita kedepannya untuk memajukan bangsa Indonesia dengan itu pembelajaran PKn perlu diajarkan secara baik agar dalam diri kita tumbuh akan kesadaran betapa pentingnya memiliki jiwa nasionalisme (Suryana, 2021). 
4829 Peran Guru dalam Meningkatkan Jiwa Nasionalisme Siswa Sekolah Dasar melalui Pembelajaran Pkn di Era Globalisasi - Ghina Fauziah Hazimah, Nabila Ratri Widya Astuti, Dinie Anggraeni Dewi, Yayang Furi Furnamasari

DOI: https://doi.org/10.31004/edukatif.v3i6.1566

\section{METODE PENELITIAN}

Dalam penelitian ini penulis menggunakan penelitian kualitatif dengan analisis deskritif melalui pendekatan studi literatur dari berbagai buku,artikel, jurnal dan berbagai karya tulis ilmiah yang telah kredible dan dapat dipertanggungjawabkan serta relevan dengan topik penelitian. Proses pengumpulan data yang dilakukan pertama pencarian jurnal-jurnal yang sesuai dengan penelitian ini lalu dianalisis dan mengutip teori yang sesuai. Pada proses pengumpulan data dan analisis pneliti juga berpedoman terhadap literatur dan sumber yang sudah ada (Zed Mestika., 2008)

\section{HASIL DAN PEMBAHASAN PENELITIAN}

\section{Pengaruh Globalisasi Terhadap Pendidikan dan Generasi Bangsa Serta Solusinya}

Era globalisasi dimulai dengan ditandai adanya hubungan kerja sama antar negara hingga antarnegara tersebut mengabaikan batasannya. Dampak negatif dari hubungan kerja sama yaitu persaingan-persaingan akan semakin ketat terutama pada bidang ekonomi. Globalisasi dapat diartikan juga sebagai proses keterikatannya yang mendunia antarindividu, bangsa dan Negara, dan organisasi-organisasi kemasyarakatan. Proses tersebut dibantu dengan alat komunikasi serta transportasi yang sudah berteknologi canggih, serta dibarengi dengan nilai-nilai sosial-budaya yang saling mempengaruhi (Fauziah, T., Maksum, H., \& Bermawi, 2016)

Pengaruh-pengaruh globalisasi menimbulkan dampak positif dan negatif terhadap dunia pendidikan. Dampak positif globalisasi terhadap pendidikan diantaranya.

1. Dapat mengakses informasi dengan mudah

Semakin canggihnya teknologi, peserta didik dapat mengakses informasi seputar pendidikan dengan mudah dan cepat. Contohnya untuk mengakses materi belajar, mengunduh buku digital dan sebagainya.

2. Meningkatnya kualitas pendidik

Pendidik sekarang dapat memanfaatkan kemajuan teknologi yang semakin canggih. Dengan begitu pendidik dapat mengetahui dengan mudah trend pembelajaran di dunia, dan juga dapat mencari referensi-referensi proses belajar mengajar pada Negara maju.

3. Meningkatnya kualitas pendidikan

Adanya arus globalisasi yang sangat pesat, dapat merubah metode pembelajaran dari sederhana menjadi metode pendidikan berbasis teknologi. Contohnya saat zaman dahulu guru menulis materi pembelajaran di papan tulis menggunakan kapur, namun sekarang dengan adanya teknologi guru dapat memberikan materi melalui power point, sumber video dari youtube, dan sebagainya.

4. Siswa didorong untuk menciptakan karya yang inovatif

Sistem pembelajaran dengan metode satu arah dikatakan kurang efektif dalam perkembangan siswa, oleh karena itu pendidik perlu meningkatkan metode pembelajaran yang digunakan seperti metode student oriented yang bisa merangsang daya pikir siswa dan juga meningkatkan keaktifan dalam proses pembelajaran.

Selain globalisasi memberikan dampak positif, globalisasi juga memberikan dampak negatif terhadap dunia pendidikan diantaranya.

1) Tingkat kualitas moral siswa menjadi rendah

Mengakses internet yang dilakukan dengan mudah juga dapat berdampak negatif pada perkembangan moral siswa, sebagai contoh situs-situs pornografi, foto dan video yang tidak 
4830 Peran Guru dalam Meningkatkan Jiwa Nasionalisme Siswa Sekolah Dasar melalui Pembelajaran Pkn di Era Globalisasi - Ghina Fauziah Hazimah, Nabila Ratri Widya Astuti, Dinie Anggraeni Dewi, Yayang Furi Furnamasari

DOI: https://doi.org/10.31004/edukatif.v3i6.1566

pantas merajarela di media sosial tanpa adanya filterisasi. Adanya konten-konten tersebut bisa berdampak pada perilaku siswa. Oleh Karena itu orang tua harus mengkontrol dan mengawasi anak bila bermain media sosial.

2) Tingkat kesenjangan social semakin tinggi

Pendidikan berbasis teknologi nyatanya perlu diimbangi dengan kesiapan mental dan modal yang tentunya tidak sedikit. Di beberapa Negara khususnya Negara berkembang perkembangan teknologi hanya bisa dimanfaatkan oleh sekolah di wilayah perkotaan, sementara sekolah di wilayah pedalaman akan terasa sulit mengakses dan kurangnya modal.

3) Tergerusnya budaya lokal

Pengaruh globalisasi dalam dunia pendidikan yang digerakkan oleh Negara-negara maju bias menjadi suatu masalah bagi Negara berkembang, tidak terkecuali Indonesia. Akibatnya budaya Indonesia dikhawatirkan akan mulai hilang karena pudarnya rasa nasionalisme, serta gaya hidup yang kebarat-baratan.

4) Timbulnya tradisi serba cepat dan instan

Orientasi pendidikan pada awalnya menekankan pada proses telah berubah kranah pencapaian hasil. Akibatnya kebanyakan siswa yang hanya menekankan pada hasil akhir saja ketika menempuh pendidikan.

Untuk menjawab semua permasalahan diatas diperlukan paradigma baru pendidikan. (Tilaar, 2007) mengemukakan adanya pokok-pokok paradigma baru pendidikan sebagai berikut: (1) pendidikan bertujuan untuk membentuk masyarakat yang berdemokratis, (2) untuk menumbuhkan masyarakat demokratis diperlukannya pendidikan, (3) pendidikan diarahkan untuk mengembangkan behaviorisme yang menjawab berbagai tantangan internal global, (4) pendidikan harus melahirkan suatu bangsa yang bersatu dan berdemokratis, (5) dalam menghadapi kehidupan yang kompetitif dan inovatif, pendidikan perlu mengembangkan kemampuan berkompetisi dalam rangka kerjasama, (6) pendidikan harus mampu mengembangkan kebhinekaan menuju kepada terciptanya suatu masyarakat Indonesia yang bersatu di atas kekayaan kebhinekaan masyarakat, dan (7) yang paling penting, pendidikan harus mampu meng-Indonesiakan masyarakat Indonesia sehingga setiap insan Indonesia merasa bangga menjadi warga negara Indonesia.

Globalisasi yang mengarahkan kepada gaya hidup kebarat-baratan cenderung menurunkan nilai-nilai kearifan lokal. Ini akan bertentangan dengan fakta bahwa manusia pertama kali tumbuh di lingkungan dan budayanya sendiri. Oleh karena itu, hanya nilai-nilai global yang terlibat dalam pemeliharaan dan pengembangan nilai-nilai lokal saja yang perlu disimak untuk diterapkan dalam proses pendidikan suatu masyarakat atau bangsa. (Tilaar, 2007) Masalah-masalah tersebut muncul karena belum semua masyarakat bangga sebagai warga Negara Indonesia. Dan di sini pemimpin formal dan informal harus menjadi panutan di semua bidang kehidupan. Untuk mencapai tujuan tersebut, perlu diselenggarakan pendidikan nasional yang baru berdasarkan prinsip-prinsip sebagai berikut: (1) partisipasi masyarakat dalam pengelolaan pendidikan, (2) demokratisasi proses pendidikan, (3) sumber daya pendidikan yang profesional, dan (4) fasilitas yang memadai.

Upaya-upaya yang dilakukan untuk mengatasi dampak negatif dari arus globalisasi antara lain, mencintai produk dalam negeri, menyaring budaya asing sesuai dengan panduan nilai, norma, dan keyakinan agama, memahami nilai-nilai pancasila dengan baik, dan meningkatkan daya potensi nasional (Irmania, 2021). Dalam (Mutmainah, S. U., \& Dewi, 2021) upaya lain yang tak kalah penting yaitu pengembangan karakter peserta didik. Pengembangan karakter dapat dilakukan melalui pendidikan dimana dalam pelaksanaannya dapat dilakukan dengan menerapkan beberapa strategi diantaranya yaitu penyadaran, pembudayaan, dan pemberdayaan juga kerja sama. 
4831 Peran Guru dalam Meningkatkan Jiwa Nasionalisme Siswa Sekolah Dasar melalui Pembelajaran Pkn di Era Globalisasi - Ghina Fauziah Hazimah, Nabila Ratri Widya Astuti, Dinie Anggraeni Dewi, Yayang Furi Furnamasari

DOI: https://doi.org/10.31004/edukatif.v3i6.1566

\section{Paradigma Pendidikan Kewarganegaraan}

Pembelajaran PKn di sekolah perlu memenuhi standar-standar ilmiah. Dengan begitu, para siswa akan memiliki pengetahuan PKn secara objektif dan tidak berdasarkan kepada pengetahuan subjektif saja. Mengingat pentingnya pembangunan karakter siswa, meskipun pendidikan PKn sudah dilakukan oleh keluarga dan masyarakat, akan lebih baik kalau juga dilakukan sekolah. Yang menjadi masalah adalah paradigma pendidikan PKn seperti apakah yang dikembangkan sekolah-sekolah selama ini (Magdalena, I., Haq, A. S., \& Ramdhan, 2020). Karena siswa masih melakukan penyimpangan moral, dan masih adanya keretakan sosial bernuansa PKn. Pendidikan kewarganegaraan di sekolah dikatakan masih jauh dari perannya dalam membangun moral bangsa. Salah kaprah mengenai pendidikan PKn juga menyebabkan menyempitnya ruang lingkup pendidikan PKn di sekolah-sekolah.

Berdasarkan aspek di atas, aspek pendidikan kewarganegaraan di sekolah harus diprioritaskan dan diterapkan pada bahan ajar sebagai berikut; Pertama, pendidikan kewarganegaraan harus memprioritaskan aspek-aspek kewarganegaraan yang dihasilkan. Mengajak dan melatih siswa untuk mengamalkan nilai-nilai pancasila pembudayaan Nilai-nilai Pancasila sangat penting dilakukan agar dapat diimplementasikan dalam kehidupan sehari-hari (Septian, 2020), contohnya yaitu seperti dengan mengajarkan siswa menjaga kebersihan, bersikap jujur dalam ujian, tolong menolong, menghargai orang lain. Ajari siswa untuk membelanjakan uang saku mereka untuk disumbangkan kepada yang membutuhkan. Mengajak siswa untuk saling mengunjungi dan melakukan kegiatan bersama untuk mengembangkan sikap nasionalisme, menghargai, toleransi dan kerjasama antar warga. Kedua, dimensi eksperiensial digarap dengan upaya-upaya menghadirkan Tuhan dalam kesadaran siswa di setiap saat dalam ketakjuban pada keindahan, keagungan, dan kecanggihan alam semesta yang diciptakan Tuhan, serta dalam aktivitas sehari-hari siswa. Dengan begitu, Tuhan tidak hanya dihadirkan pada momen-momen eksklusif ritual saja, melainkan terus menerus dalam setiap langkah kehidupan.

Ketiga, perlakuan terhadap dimensi ideologis dilakukan dengan mengutamakan perlunya sikap nasionalis. Percaya pada kebenaran yang dipahami siswa tidak boleh menimbulkan fanatisme sempit, arogansi agama, kelumpuhan akal, dan sikap anti dialog. Kebenaran ilahi tersebar di mana-mana. Tanpa kesadaran ini, orang dengan mudah terjerumus ke dalam tindakan lain dengan dalih penyelamatan, yang mengarah pada perpecahan sosial.

\section{Pentingnya Pembelajaran PKn di Sekolah Dasar}

PKn merupakan mata pelajaran yang wajib di sekolah-sekolah formal di Indonesia termasuk pada jenjang Sekolah Dasar. PKn adalah salah satu lintasan yang dapat menuntun warga Indonesia menjadi seorang warga negara yang baik. Perubahan sosial yang terjadi di tengah arus globalisasi ini tak jarang menyebabkan lunturnya jiwa nasionalisme di kalangan generasi muda bangsa Indonesia. PKn mempunyai peran besar dalam mengatasi hal-hal tersebut. Dimana melalui PKn moral generasi muda dapat dikembangkan seperti yang dikehendaki oleh bangsa. PKn juga menjadi bekal pembangunan bangsa dimana dengan pendidikan kewarganegaraan ini generasi muda memiliki wawasan yang luas tentang Negaranya sehingga menumbuhkan semangat untuk membangun bangsa Indonesia di masa depan serta senantiasa menumbuhkan kecintaan terhadap bangsa Indonesia melalui pengenalan berbagai budaya dan kekayaan bangsa Indonesia yang sebelumnya tidak mereka ketahui. (Djiwandono, 2000).

Fungsi dari adanya pelajaran PKn di SD ini yaitu sebagai sarana agar siswa paham akan hak dan kewajibannya, memiliki komitmen untuk setia terhadap bangsanya, menjadi manusia yang cerdas, terampil, dan berkarakter pancasila sesuai seperti yang ada dalam amanat pancasila dan uud 1945. Adapun fungsi pembelajaran PKn di sekolah menurut (Winataputra, 2020) yaitu :

1. Menjadikan generasi muda paham akan cita-cita nasional dan paham akan tujuan negaranya 
4832 Peran Guru dalam Meningkatkan Jiwa Nasionalisme Siswa Sekolah Dasar melalui Pembelajaran Pkn di Era Globalisasi - Ghina Fauziah Hazimah, Nabila Ratri Widya Astuti, Dinie Anggraeni Dewi, Yayang Furi Furnamasari

DOI: https://doi.org/10.31004/edukatif.v3i6.1566

2. Menjadikan manusia yang bertanggung jawab dalam menyelesaikan suatu masalah yang ada baik masalah pribadi, masyarakat dan negara. Serta senantiasa adil dan bijaksana dalam mengambil setiap keputusan.

3. Menjadi generasi yang mampu mengapresiasikan cita-cita bangsa dan menjadi insan yang cerdas dalam membuat keputusan.

4. Sebagai wahana pembentukan insan yang cerdas, terampil dan setia terhadap bangsa Indonesia, dan berkarakter pancasila.

Melihat pentingnya pembelajaran PKn tersebut. Pembelajaran PKn di SD senantiasa didasarkan pada prinsip-prinsip pembelajaran yang (PAIKEM) yaitu kepanjangan dari Pembelajaran Aktif, Inovatif, Kreatif, Efektif dan Menyenangkan. Dengan prinsip tersebut tujuan pembelajaran PKn bisa tercapai dengan mudah. Adapun tujuan pembelajaran PKn itu sendiri antara lain yaitu menjadikan peserta didik berbudi luhur, mandiri, tangguh, bertanggungjawab, professional, produktif dan sehat jasmani serta rohaninya. Dengan adanya pembelajaran PKn yang efektif ini juga peserta didik akan cinta terhadap tanah airnya, memiliki ketahanan nasional yang kuat dan menjadi penerus bangsa yang berprestasi serta .memiliki ilmu pengetahuan yang luas dan menguasai teknologi dan juga seni.(Dewi, 2020).

\section{Peran Guru dalam Meningkatkan Jiwa Nasionalisme Siswa SD melalui Pembelajaran PKn}

Dalam pendidikan guru berperan penting dalam pembentukan sikap dan karakter peserta didiknya di sekolah untuk dapat memiliki rasa nasionalisme yang tinggi pada dirinya. Rasa nasionalisme itu sendiri adalah suatu sikap yang harus dimiliki setiap peserta didik sebagai modal pembangunan negara dan kelangsungan kehidupan berbangsa dan bernegara. Dalam pembelajaran guru tidak hanya berperan sebagai penyampai materi lebih dari itu guru harus menjadikan materi pembelajaran itu dapat diterima dengan baik oleh peserta didik dan dalam pembelajarannya peserta didk merasa senang sehingga rasa nasionalisme pada jiwa peserta didik dapat terbentuk.

Adapun upaya-upaya yang dapat dilakukan oleh guru dalam menumbuhkan sikap nasionalisme pada diri peserta didik melalui pembelajaran PKn yaitu (Oktafani, 2019):

1. Peran guru sebagai korektor, yaitu guru berperan untuk menegur, menasehati dan juga memberikan contoh yang baik kepada siswa nya. hal ini dapat dilakukan dengan menegur siswa yang sering terlambat, menegur siswa yang membolos dan tidak mengikuti upacara. Dan senantiasa mencontohkan sikap-sikap disiplin di sekolah. Hal ini agar siswa tidak memiliki kebiasaan yang buruk dalam kehidupannya.

2. Peran guru sebagai inspirator, yaitu guru harus mampu menginspirasi peserta didiknya untuk mengoptimalkan bakat dan potensi yang ada pada diri peserta didik. Dan juga mengubah pola pikir peserta didik bahwa pembelajaran itu hanya berupa materi saja namun bisa dari hal-hal yang ada di sekitar serta kehebatan peserta didik tidak hanya dilihat dari nilai akademik saja namun berbagai keahlian pada diri siswa.

3. Peran guru sebagai informan, yaitu guru memberikan berbagai informasi tentang siswa tentang materi-materi PKn seperti mengenalkan lambing negara, pahlawan nasional, dasar negara, budaya bangsa dan yang lainnya dengan cara yang sekiranya membuat siswa senang dan semangat dalam belajar.

4. Peran guru sebagai motivator, yaitu guru harus dapat memberikan motivasi kepada peserta didik untuk berfikir secara kronologis dan dapat menempatkan diri di masa kini. Hal ini dapat dilakukan guru dengan bercerita tentang bebagai tokoh-tokoh pahlawan dengan berbagai sikap-sikap positif yang dimilikinya. 
4833 Peran Guru dalam Meningkatkan Jiwa Nasionalisme Siswa Sekolah Dasar melalui Pembelajaran Pkn di Era Globalisasi - Ghina Fauziah Hazimah, Nabila Ratri Widya Astuti, Dinie Anggraeni Dewi, Yayang Furi Furnamasari

DOI: https://doi.org/10.31004/edukatif.v3i6.1566

5. Peran guru sebagai pembimbing, yaitu guru mengajarkan sisa untuk mampu memecahkan masalah sehingga siswa mampu mengerjakan berbagai tugas yang guru berikan. Bimbingan ini dapat dilakukan dengan mengajarkan siswa untuk tolong menolong, bagaimana cara berterimakasih, bagaimana sikap peduli lingkungan dan bagaimana hidup rukun dan masih banyak lagi sampai anak paham dan mampu menerapkan hal-hal tersebut secara mandiri.

6. Peran guru sebagai fasilitator, yaitu dengan guru memfasilitasi siswa untuk lebih mudah memahami materi dan pembelajaran yang disampaikan yaitu guru menyediakan berbagai alat penunjang seperti menyediakan buku, memutarkan video, dan memberi akses anak untuk dapat mengunjungi berbagai tempat bersejarah.

7. Peran guru sebagai demonstrator, yaitu guru harus mampu memperlihatkan gambaran suatu kejadiankejadiian baik melalui media maupun melalui diri sendiri tentang berbagai peristiwa-peristiwa penting atau bersejarah agar anak dapat mengambil makna dan nilai-nilai positif yang ada pada kejadian tersebut.

Dalam menjalankan perannya tersebut guru dapat memanfaatkan hal-hal yang ada di sekitar seperti keberagaman disekolah serta membuat berbagai kegiatan-kegiatan yang menyenangkan yang mencerminkan sikap nasionalisme untuk siswa. Dalam proses pembelajaran kesiapan guru dalam mengajar juga tak kalah penting agar guru dapat senantiasa menjawab pertanyaan-pertanyaan dari siswa. Serta guru juga harus terampil dalam menyampaikan materi serta memahami berbagai karakter siswanya sehingga suasana belajar yang baik dapat tercipta dan tujuan pembelajaran dapat tercapai secara optimal. (Suyadi, 2013).

\section{Kendala dan Upaya yang Dapat Dilakukan Guru dalam Menumbuhkan Jiwa Nasionalisme terhadap Peserta Didik}

Menurut salah satu jurnal dalam menumbuhkan jiwa nasionalisme memiliki beberapa kendala yaitu diantaranya adalah (Oktafani, 2019):

1. pembentukan sikap nasionalisme pada anak tak lepas dari pengaruh dari pendidikan yang ada dalam keluarga sang anak. Sifat dan karakter anak dilator belakangi dari bagaimana anak tersebut dperlakukan di rumah. Seperti sifat manja pada anak hal ini bisa saja terjadi karena orang tua sang anak adalah orang yang berkecukupan sehingga anak selalu mendapatkan apa yang di inginkannya dengan mudah.

2. pengaruh media sosial, denga adanya media sosial siswa anak senantiasa dimudahkan dan tidak perlu bersusah payah lagi untk mendapatkan apa yang mereka inginkan, perkembangan alat komunikasi juga dapat mempengaruhi pola pikir anak jika anak kurang bijaksana dalam menggunakan teknologi tersebut penumbuhan jiwa nasioalisme anak juga dapat terhambat.

3. Pemberitaan di media sosial, dengan adanya media seperti televisi anak sering melihat berbagai pemberitaan tentang masalah-masalah yang terjadi di Indonesia seperti korupsi, pencurian, tawuran dan yang lainnya dan tak jarang hal tersebut dilakukan oleh para tokoh negara dan publick figure membuat anak bingung dengan negara nya dan tidak mempunyai tokoh yang patut untuk mereka contoh.

4. Fasilitas sekolah yang kurang memadai seperti kurangnya buku-buku sejarah, akses internet dan berbagai sarana prasana lain yang dibutuhkan dalam proses pembelajaran.

Dalam menumbuhkan sikap nasionalisme dibutuhkan kerjasama dari semua pihak. Baik guru, sekolah dan juga orang tua. Dengan adanya kerjasama dari berbagai pihak kendala-kendala tersebut dapat teratasi. Orangtua dapat menjadi kontrol anaknya jika dirumah sedangkan guru dan sekolah sebagai pengupaya 
4834 Peran Guru dalam Meningkatkan Jiwa Nasionalisme Siswa Sekolah Dasar melalui Pembelajaran Pkn di Era Globalisasi - Ghina Fauziah Hazimah, Nabila Ratri Widya Astuti, Dinie Anggraeni Dewi, Yayang Furi Furnamasari

DOI: https://doi.org/10.31004/edukatif.v3i6.1566

terciptanya pembelajaran PKn yang efektif guna menumbuhkan jiwa nasionalisme pada anak. Menurut (Lestari, 2019) penerapan nilai-nilai pancasila juga harus senantiasa diajarkan pada anak baik di rumah, sekolah dan juga di dalam masyarakat agar jiwa nasionalisme itu sendiri senantiasa tercermin pada diri anak kapanpun dan dimanapun dirinya berada.

\section{KESIMPULAN}

Pendidikan Kewarganegaraan merupakan hal yang penting dan tidak dapat dipandang sebelah mata. Oleh karena itu pelajaran PKn ini menjadi mata pelajaran wajib di sekolah-sekolah di Indonesia. Dalam pembelajaran PKn di sekolah dasar selain mengajarkan secara teori guru juga berperan sebagai seorang panutan yang dapat memberikan contoh perilaku yang baik terhadap siswanya dan dapat menanamkan rasa cinta terhadap budaya bangsa Indonesia sehingga jiwa nasionalisme dapat tumbuh di diri siswa di tengah era globalisasi seperti saat ini.

\section{UCAPAN TERIMA KASIH}

Puji syukur kepada Tuhan Yang Maha Esa karena berkat kehendaknya kami dapat menyelesaikan penelitian berdasarkan studi literatur yang berjudul Peran Guru Dalam Meningkatkan Jiwa Nasionalisme Siswa Sekolah Dasar Melalui Pembelajaran PKn di Era Globalisasi. Tak lupa ucap terima kasih kepad seluruh pihak yang telah berkontribusi bersama dalam penelitian ini.

\section{DAFTAR PUSTAKA}

Dewi, N. P. C. P. (2020). Buku Ajar Mata Pelajaran Sekolah Dasar Pkn Dan Pancasila. In Bali: Nilacakra.

Djiwandono, J. S. (2000). "Globalisasi Dan Pendidikan Nilai" Dalam Sindhunata (Ed), Menggagas Paradigma Baru Pendidikan: Demokratisasi, Otonomi, Civil Society, Globalisasi. In Yogyakarta: Kanisius.

Fauziah, T., Maksum, H., \& Bermawi, Y. (2016). Peran Pendidikan Kewarganegaraan Di Era Globalisasi Dalam Menumbuhkan Semangat Nasionalisme. In Aceh: Jurnal Pendidikan Serambi Ilmu.

Fitrayadi, D. S. (2016). Peran Pendidikan Kewarganegaraan Dalam Mengembangkan Karakter Tanggungjawab Peserta Didik Di Era Globalisasi Di Sma Negeri 1 Baleendah. Untirta Civic Education Journal, 1(2).

Irhandayaningsih, A. (2012). Peranan Pancasila Dalam Menumbuhkan Kesadaran Nasionalisme Generasi Muda Di Era Global. Humanika, 16(9).

Irmania, E. (2021). Upaya Mengatasi Pengaruh Negatif Budaya Asing Terhadap Generasi Muda Di Indonesia. Jurnal Dinamika Sosial Budaya, 23(1), 149-160.

Lestari, E. Y. (2019). Menumbuhkan Kesadaran Nasionalisme Generasi Muda Di Era Globalisasi Melalui Penerapan Nilai-Nilai Pancasila. Adil Indonesia Journal, 1(1).

Magdalena, I., Haq, A. S., \& Ramdhan, F. (2020). Pembelajaran Pendidikan Kewarganegaraan Di Sekolah Dasar Negri Bojong 3 Pinang. Bintang, 2(3), 418-430.

Mutmainah, S. U., \& Dewi, D. A. (2021). Reaktualisasi Nilai Pancasila Dan Implementasinya Sebagai Upaya Pembangunan Karakter Bangsa. Edukatif: Jurnal Ilmu Pendidikan, 3(2), 611-618.

Oktafani, A. (2019). Peran Guru Sejarah Dalam Membentuk Sikap Nasionalisme Peserta Didik Di Sman 8 Padang. Jurnal Kapita Selekta Geografi, 2(4).

Rahayu, M. (2007). Pendidikan Kewarganegaraan Perjuangan Menghidupi Jati Diri Bangsa. In Depok: Pt 
4835 Peran Guru dalam Meningkatkan Jiwa Nasionalisme Siswa Sekolah Dasar melalui Pembelajaran Pkn di Era Globalisasi - Ghina Fauziah Hazimah, Nabila Ratri Widya Astuti, Dinie Anggraeni Dewi, Yayang Furi Furnamasari

DOI: https://doi.org/10.31004/edukatif.v3i6.1566

Grasindo.

Sakman, S., \& Bakhtiar, B. (2019). Pendidikan Kewarganegaraan Dan Degradasi Moral Di Era Globalisasi. Jurnal Pemikiran, Penelitian Ilmu-Ilmu Sosial, Hukum Dan Pengajarannya, 14(1).

Septian, D. (2020). Pemahaman Nilai-Nilai Pancasila Dalam Memperkuat Kerukunan Umat. Tanjak: Journal Of Education And Teaching, 1(2), 155-168.

Suryana, D. (2021). Lunturnya Rasa Nasionalisme Pada Anak Milenial Akibat Arus Modernisasi. Edukatif: Jurnal Ilmu Pendidikan, 3(2), 598-602.

Suyadi. (2013). Strategi Pembelajaran Pendidikan Karakter. In Bandung: Remaja Rosdakarya.

Tilaar, H. A. R. (2007). Mengindonesia Etnisitas Dan Identitas Bangsa Indonesia. In Jakarta :Rineka Cipta (Pp. 19-23).

Wahyudi, W. (2016). Reaktualisasi Nilai-Nilai Pancasila Dalam Pembangunan Karakter Bangsa Indonesia. Inprosiding Seminar Nasional Inovasi Pendidikan.

Winataputra, H. U. S. (2020). Hakikat, Fungsi, Dan Tujuan. Pembelajaran Pkn Di Sd, 1(1).

Zed Mestika. (2008). Metode Penelitian Kepustakaan. In Jakarta: Yayasan Obor Indonesia. 